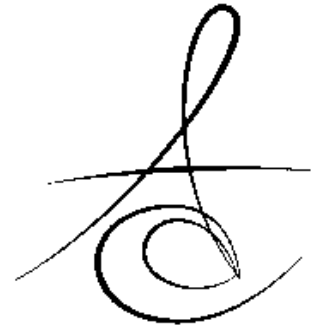

Makale Kodu/Article code: 1579

Makale Gönderilme tarihi: 16.03 .2014

Kabul Tarihi: 28.04.2014

\title{
EVALUATION OF TOTAL AND PARTIAL EDENTULOUS JAWS USING PANORAMIC RADIOGRAPHY
}

\section{TOTAL VE PARSİYEL DİŞSİZ ÇENELERİN PANORAMİK RADYOGRAFI} KULLANILARAK DEĞERLENDİRİLMESİ

\author{
Doç. Dr. İlkay PEKER
}

Dr. Arzu Zeynep YILDIRIM-BİÇER ${ }^{* *}$

\section{ABSTRACT}

Aim: Panoramic radiography is a diagnostic modality for providing a view of the entire maxillofacial region and used as an initial screening tool to examine partially and completely edentulous jaws in pretreatment assessment.

Material-method: This study included digital panoramic images of 321 partially and totally edentulous patients. The images were evaluated for positive radiographic findings including presence of retained root fragments, impacted teeth, radiolucencies, radiopacities, proximity of the mental foramen and maxillary sinus to the residual alveolar ridge.

Results: Totally 538 edentulous jaws were examined in 321 individuals (51.1\% females, $48.9 \%$ males) mean aged 57.3 (standard deviation $=11.5$ ). The rate of completely edentulous jaws was $29 \%(n=156)$ and the rate of partially edentulous jaws was $71 \%$. Prevalence of one or more positive radiographic findings was found to be $51 \%$. Of the radiographic findings, $49.4 \%$ was in females and $50.6 \%$ in males. The most frequent finding was retained root fragments $(15.6 \%)$, followed by location of the maxillary sinus close to the alveolar crest $(10.6 \%)$, radioopacities $(9.3 \%)$, impacted teeth $(8 \%)$, location of the mental foramen on the crest $(6.8 \%)$ and radiolucencies (1.2\%).

Conclusion: Prevalence of positive radiographic findings was found to be relatively high in clinically healthy looking edentulous patients in this study. This result confirmed that pretreatment panoramic examination is necessary to detect pathologies and requirement of any dental procedure for a successful prosthodontic rehabilitation.

Key words: Panoramic radiography, edentulous patients, radiographic evaluation

\section{ÖZET}

Amaç: Panoramik radyografi tüm maksillofasiyal bölgenin görülmesine olanak sağlayan bir diagnostik yöntemdir ve parsiyel ve tam dişsiz çenelerin tedavi öncesi değerlendirmesinde ilk inceleme yöntemi olarak kullanılır.

Gereç ve yöntem: Bu çalışmada 321 parsiyel ve total dişsiz hastanın dijital panoramik görüntüsü incelendi. Görüntüler, kök artıkları, gömülü dişler, radyolusensiler, radyoopasiteler, mental foramen ve maksiller sinüsün alveolar kret tepesine yakınlığı gibi pozitif radyografik bulgular yönünden değerlendirildi.

Bulgular: Yaş ortalaması 57.3 (standart sapma=11.5) olan 321 (\% 51.1 kadın, \% 48.9 erkek) hastada toplam 538 dişsiz çene incelendi. Total dişsiz çenelerin oranı \% $29(n=156)$ ve parsiyel dişsiz çenelerin oranı ¡\% 71'di. Bir veya daha fazla pozitif radyografik bulguların görülme sıklığı, \% 51 olarak bulundu. Bunların \% 49.4'ü kadın, \% 50.6'sı erkeklerdeydi. En fazla görülen bulgu artık köklerdi (\% 15.6), bunu maksiller sinüsün alveolar krete yakınlığı (\% 10.6), radyoopasiteler (\% 9.3), gömülü dişler (\% 8), mental foramenin alveolar krete yakınlığı (\% 6.8) ve radyolusensiler (\% 1.2) takip etmekteydi.

Sonuç: Bu çalışmada klinik olarak sağlıklı görünen dişsiz hastalardaki pozitif radyografik bulguların görülme sıklığı, göreceli olarak yüksek bulundu. Bu sonuç başarılı bir prostodontik tedavi için herhangi bir işlemin gerekliliğini ve patolojilerin belirlenmesi için tedavi öncesinde panoramik radyografinin gerekliliğini doğrulamaktadır.

Anahtar kelimeler: Panoramik radyografi, dişsiz hastalar, radyografik değerlendirme

* $^{*}$ University Faculty of Dentistry, Department of Dentomaxillofacial Radiology,

** Gazi University Faculty of Dentistry, Department of Prosthetic Dentistry 


\section{INTRODUCTION}

Panoramic radiography is a diagnostic modality for providing a view of the entire maxillofacial region. It is frequently used as an initial screening tool to examine partially and completely edentulous jaws in pretreatment assessment. ${ }^{1-4}$ Firstly, Logan evaluated the radiographs of edentulous jaws and detected pathologies such as root fragments and impacted teeth in $28.6 \%$ patients. ${ }^{5,6}$

Routine panoramic examination of edentulous patients is a controversial subject and there is no agreement between the authors. Food and Drug Admininstration (FDA) and American Dental Association (ADA) suggest a full-mouth intraoral or panoramic radiographic examination for newly edentulous patients $^{7}$ On the contrary, European Guidelines on Radiation Protection in Dental Radiology doesn't suggest radiographic examination for healthy edentulous patients. ${ }^{8}$ Previous studies reported that several anatomic considerations such as location of mandibular canal, mental foramen, mucosal thickness, status of alveolar crest, relationship between alveolar crest and maxillary sinus may affect prosthetic treatment planning. ${ }^{9-11}$ Radiographic examination is necessary for evaluation of these conditions. ${ }^{5}$

Many pathologic changes are observed in radiographic examination of apparently healthy edentulous jaws during clinical examination. ${ }^{1,4}$ Although it's diagnostic advantages are clear, routine radiographic examination of edentulous patients is currently being questioned because of well known detrimental effects of radiation. ${ }^{4,12,13}$

The aim of this study was to evaluate prevalence of significant radiographic findings in panoramic radiographs of edentulous jaws. Our hypothesis was that panoramic radiographic examination is helpful for edentulous patients before prosthetic rehabilitation.

\section{MATERIAL AND METHODS}

This study included digital panoramic images of 321 partially and totally edentulous patients aged between 25 and 89 . The clinical examination was carried out and the panoramic images were obtained from clinically apparent healthy subjects for preoperative implant planning in Gazi University
Faculty of Dentistry, Department of Dentomaxillofacial Radiology (Ankara, Turkey). No additional radiographs were taken from the patients for the study. Digital panoramic images were obtained with a Orthoralix 9200 DDE (Gendex Co, Milan, Italy) panoramic unit and a CCD-based system used with VixWin 2000 software (Gendex Co, Milan, Italy). The images were examined on the monitor using 8-bit resolution.

The images were evaluated for positive radiographic findings by an oral radiologist at least 12 years of experience. The following information was considered: (1) age and sex; (2) presence of retained root fragments; (3) impacted teeth; (4) radiolucencies (5) radiopacities; (6) location of the mental foramen at the crest of the residual alveolar ridge; (7) location of the maxillary sinus close to the residual alveolar ridge. The lesions looking like odontogenic or non-odontogenic cysts were categorized as radiolucencies and osteosclerosis, fibroosseous lesions and soft tissue calcifications were categorized as radioopacities. Poor quality radiographic images were excluded. The obtained data were analyzed with descriptive statistics and cross-tabs.

\section{RESULTS}

Totally 538 jaws were examined in 321 individuals mean aged 57.3 (standard deviation= $11.5), 51.1 \%(n=164)$ were females and $48.9 \%$ $(n=157)$ were males. The rate of completely edentulous jaws was $29 \%(n=156)$ and the rate of partially edentulous jaws was $71 \%(n=382)$ (Table 1).

Table 1. Distribution of examined edentulous jaws

\begin{tabular}{|l|c|c|c|c|}
\hline \multirow{2}{*}{ Edentulous jaws } & \multicolumn{2}{|c|}{ Maxilla } & \multicolumn{2}{c|}{ Mandible } \\
\cline { 2 - 5 } & $\mathbf{N}$ & $\mathbf{\%}$ & $\mathbf{N}$ & $\mathbf{\%}$ \\
\hline Total edentulous & 89 & 27.7 & 67 & 20.9 \\
\hline Partial edentulous & 177 & 55.1 & 205 & 63.9 \\
\hline Total & 266 & 49.4 & 272 & 50.6 \\
\hline
\end{tabular}

Prevalence of one or more positive radiographic findings was found to be $51 \%(n=164)$. Of the radiographic findings, $49.4 \%(n=81)$ was in females and $50.6 \%(n=83)$ in males (Table 2). The most frequent finding was retained root fragments, followed by location of the maxillary sinus close to the

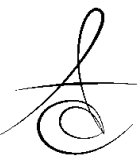


alveolar crest, radioopacities, impacted teeth, location of the mental foramen on the crest and radiolucencies (Table 2).

Table 2. Prevalence of one or more radiographic findings according to gender

\begin{tabular}{|l|c|c|c|c|c|c|}
\hline \multirow{2}{*}{ Radiographic findings } & \multicolumn{2}{|c|}{ Males } & \multicolumn{2}{c|}{ Females } & \multicolumn{2}{c|}{ Total } \\
\cline { 2 - 8 } & $\mathbf{N}$ & $\mathbf{\%}$ & $\mathbf{N}$ & $\mathbf{\%}$ & $\mathbf{N}$ & $\mathbf{\%}$ \\
\hline Root fragments & 23 & 14.6 & 27 & 16.4 & 50 & 15.6 \\
\hline Impacted teeth & 13 & 8.3 & 11 & 6.7 & 24 & 8 \\
\hline Radiolucencies & 3 & 1.9 & 2 & 1.2 & 5 & 1.2 \\
\hline Radiopacities & 14 & 8.9 & 16 & 9.7 & 30 & 9.3 \\
\hline $\begin{array}{l}\text { Location of the mental } \\
\text { foramen at the crest of the } \\
\text { residual alveolar ridge }\end{array}$ & 4 & 2.5 & 17 & 10.3 & 21 & 6.8 \\
\hline $\begin{array}{l}\text { Location of the maxillary } \\
\text { sinus close to the residual } \\
\text { alveolar ridge. }\end{array}$ & 20 & 12.7 & 14 & 8.5 & 34 & 10.6 \\
\hline
\end{tabular}

Sixty five root fragments were observed in 50 patients and the number of retained root fragments was approximately equal in maxilla and mandible (Table 3). The radioopacities were more common in mandible than in maxilla. Totally 39 impacted teeth were observed in 24 patients and 19 teeth were localized in maxilla and 20 teeth were in mandible (Table 3). The radiolucencies were approximately equal in maxilla and mandible. Impacted teeth were common in males than females and the most frequent impacted teeth was maxillary and mandibular third molars (Table 4).

\section{DISCUSSION}

Previous studies investigated positive radiographic findings in completely and partially edentulous patients in several countries and different results were reported that the prevalence of positive radiographic findings varied between $0.33 \%$ and $68 \%$. 1,4,9,10,14-21 The differences between results may arise from the considered variables, socio-cultural differences, improved technology, a greater accessibility of imaging facilities etc. In this study, one or more positive radiographic findings were found in $51 \%$ of the patients. This result is comparable with previous studies. ${ }^{1,4,9,19}$

It was reported that the most frequent finding was retained root fragments in edentulous patients. ${ }^{1,2,9,15-17,22}$ Also, this finding was observed in posterior regions of the jaws, especially in maxilla. $(1,9,15-17)$ There are many difficulties including small root fragments, limited visibility and possibility of complications due to proximity of maxillary sinus during extraction of maxillary molar teeth. ${ }^{1,18,23,24}$ In this study, the most frequent finding was retained root fragments (15.6\%) and they were most commonly located in mandibular and maxillary molar regions in accordance with previous studies.

Table 3. Distribution of evaluated positive radiographic findings according to jaws

\begin{tabular}{|c|c|c|c|c|c|c|c|c|c|}
\hline \multirow[b]{2}{*}{$\begin{array}{l}\text { Radiographic } \\
\text { findings }\end{array}$} & \multicolumn{4}{|c|}{ Regions in maxilla } & \multicolumn{2}{|c|}{ Regions in mandible } & \multicolumn{3}{|c|}{ Total } \\
\hline & $\begin{array}{c}\text { Anterior } \\
\text { n (\%) }\end{array}$ & $\begin{array}{c}\text { Premolar } \\
\text { n (\%) }\end{array}$ & $\begin{array}{l}\text { Molar } \\
\text { n (\%) }\end{array}$ & $\begin{array}{c}\text { Anterio } \\
\mathbf{r} \\
\mathbf{n}(\%)\end{array}$ & $\begin{array}{c}\text { Premolar } \\
\text { n (\%) }\end{array}$ & $\begin{array}{l}\text { Molar } \\
\text { n (\%) }\end{array}$ & $\begin{array}{c}\text { Total } \\
\text { (mandible) } \\
\text { n (\%) }\end{array}$ & $\begin{array}{c}\text { Total } \\
\text { (maxilla) } \\
\text { n (\%) }\end{array}$ & $\begin{array}{c}\text { Total (whole } \\
\text { jaws) } \\
\text { n (\%) }\end{array}$ \\
\hline Root fragments & $5(7.7)$ & $10(15.4)$ & $18(27.7)$ & $1(1.5)$ & $7(10.7)$ & $24(37)$ & $33(50.7)$ & $32(49.3)$ & $65(100)$ \\
\hline Impacted teeth & $9(23.1)$ & - & $10(25.6)$ & - & $3(7.7)$ & $17(43.6)$ & $19(48.7)$ & $20(51.3)$ & $39(100)$ \\
\hline Radiolucencies & - & $1(20)$ & - & $1(20)$ & $2(40)$ & $1(20)$ & $1(20)$ & $4(80)$ & $5(100)$ \\
\hline
\end{tabular}

Table 4. Distribution of determined impacted teeth according to gender

\begin{tabular}{|l|c|c|c|c|}
\hline Regions of jaws & Teeth & Males & Females & Total \\
\hline \multirow{3}{*}{ Maxillary canines } & $\mathbf{1 3}$ & $4(66.7)$ & $2(33.3)$ & $6(100)$ \\
\cline { 2 - 5 } & $\mathbf{2 3}$ & $1(33.3)$ & $2(66.7)$ & $3(100)$ \\
\hline \multirow{3}{*}{ Maxillary molar } & $\mathbf{1 8}$ & - & $4(100)$ & $4(100)$ \\
\cline { 2 - 5 } Mandibular premolar & $\mathbf{2 8}$ & $1(16.7)$ & $5(83.3)$ & $6(100)$ \\
\cline { 2 - 5 } & $\mathbf{3 4}$ & $1(100)$ & - & $1(100)$ \\
\hline \multirow{3}{*}{ Mandibular molar } & $\mathbf{4 6}$ & $1(50)$ & $1(50)$ & $2(100)$ \\
\cline { 2 - 5 } & $\mathbf{3 8}$ & $5(100)$ & - & $2(100)$ \\
\cline { 2 - 5 } & $\mathbf{4 8}$ & $6(85.7)$ & $3(37.5)$ & $8(100)$ \\
\hline \multicolumn{2}{|c|}{ Total } & $21(53.8)$ & $18(46.2)$ & $7(100)$ \\
\hline
\end{tabular}

The amount of available bone between floor of maxillary sinus and alveolar crest is an important factor in preoperative implant placement with respect to decision of sinus lifting necessity. ${ }^{9}$ Similarly, distance between mental foramen and the alveolar crest is another important factor in edentulous patients. When mental foramen positioned directly at the alveolar crest, some complaints such as pain and numbness can appear because of compression of prosthesis to mental nerve. ${ }^{5}$ Panoramic radiography is 
accepted reliable imaging method for measurements and investigations in vertical direction. (9,25,26) Prevalence of maxillary sinus close to the alveolar crest found to be $8.6 \%$ and $30.6 \% 4,9$ and prevalence of location of the mental foramen at the crest of the residual alveolar ridge reported as $1.7 \%, 4.4 \%$ and $14 \%$ in previous studies for edentulous patients. ${ }^{4,5,9}$ In this study, maxillary sinus close to the alveolar crest and location of the mental foramen at the crest of the residual alveolar ridge were found as $10.6 \%$ and 6.8 $\%$, respectively. This result is comparable with previous studies. ${ }^{4,9}$

Previous studies evaluated prevalence of radioopacities and radiolucencies in edentulous patients. The prevalence of radioopacities was reported as $12.1 \%, 4.8 \%$ and $12.9 \% .4,5,9$ Several radiolucencies were found in edentulous patients $(9,23,27)$ and the prevalence of radiolucencies was reported as $0.9 \%, 2.2 \%$ and $9.9 \% .{ }^{4,5,9}$ In this study, the rates of radioopacities and radiolucencies were found to be $9.3 \%$ and $1.2 \%$, respectively. The results of the present study were in accordance with previous studies.

The prevalence of positive radiographic findings such as retained root fragments, impacted teeth, radioopaque, radiolucent lesions etc. is generally high in edentulous patients. The results of this study supported that our hypothesis was that panoramic radiography may be helpful for edentulous patients. Sumer et al. ${ }^{9}$ suggested that routine panoramic examination is necessary in edentulous patients to detect required treatment procedures before prosthetic rehabilitation. This point of view was supported by Jindal et al. ${ }^{5}$ However, Masood et al. ${ }^{1}$ and Awad et al. ${ }^{4}$ disagreed with mentioned authors related with necessity of routine panoramic examination in edentulous patients due to the positive radiographic findings rarely require any treatment.

\section{CONCLUSION}

Prevalence of positive radiographic findings was found to be relatively high in clinically healthy looking edentulous patients in this study. Prevalence of positive radiographic findings was found to be relatively high in clinically healthy looking edentulous patients in this study. This result confirmed that pretreatment panoramic examination is necessary to detect pathologies and requirement of any dental procedure for a successful prosthodontic rehabilitation.

\section{REFERENCES}

1. Masood F, Robinson W, Beavers KS, Haney KL. Findings from panoramic radiographs ofthe edentul ous population and review ofthe literature.Quintess ence Int 2007;38:e298-305.

2. Rushton $\mathrm{VE}$, Horner $\mathrm{K}$. The use of panoramic radiology dental practice. J Dent 1996;24:187-201.

3. White SC, Pharoah MJ. Oral Radiology:Principles and Interpretation. 3. ed St. Louis: Mosby: 2003.

4. AwadEA, AIDharrabA.Panoramic radiographic exam ination a survey of 271 edentulous patients. Int J Prosthodont 2011;24:55-7.

5. Jindal SK, Sheikh S, Kulkarni S, Singla A. Significance of pre-treatment- panoramic radiographic assessment of edentulous patients-a survey. Med Ora Pato Oral Cir Bucal 2011; 16:e600-6.

6. Michaeli Y, Hermel J, Gizenfeld E, Michman J. Pathologic radiographic findings in clinically symptom-free edentulous subjects. Oral Surg Oral Med Oral Pathol 1968;26:27-30.

7. Bohay RN, Stephens RG, Kogon SL. A study of the impact of screening or selective radiography on the treatment and postdelivery outcome for edentulous patients. Oral Surg Oral Med Oral Pathol Oral Radiol Endod 1998;86:353-9

8. Martinez Beney to $Y$, Alcaraz Banos $M$, Perez Lajarin L, Rushton VE. Clinical justification of dental radiology in adult patients: a review of the literature. Med Oral Patol Oral Cir Bucal 2007; 12:E244-51.

9. Sumer $P$, Sumer $M$, Guler AU, Bicer I. Panoramic radiographic examination of edentulous mouths. Quintessence Int 2007;38:614.e399-403.

10. Perrelet LA, Bernhard M, Spirgi M. Panoramic radiography in the examination of edentulous patients. J Prosthet Dent 1977;37:494-8.

11. Seals RR, Williams EO, Jones JD. Panoramic radiographs: Necessary for edentulous patients? J Am Dent Assoc 1992;123:74-8.

12. Garcia RI, Valachovic RW, Chauncey HH. Longitudinal study of the diagnostic yield of panoramic radiographs in aging edentulous men. Oral Surg Oral Med Oral Pathol 1987;63:494-7. 
13. Zeicher SJ, Ruttimann UE, Webber RL. Dental radiography: Efficacy in the assessment of intraosseous lesions of the face and jaws in asymptomatic patients. Radiology 1987;1962:6915.

14. Lyman S, Boucher L. Radiographic examination of edentulous mouths. J Prosthet Dent 1990; 64: 180-2.

15. Lloyd PM, Gambert SR. Periodic oral examinations and panoramic radiographs in edentulous elderly men. Oral Surg Oral Med Oral Pathol 1984; 57: 678-80.

16. Jones JD, Seals RR, Schelb E. Panoramic radiographic examination of edentulous patients. ] Prosthet Dent 1985;53:535-9.

17. White SC, Forsythe $A B$, Joseph LP. Patientselection criteria for panoramic radiography. Oral Surg Oral Med Oral Pathol 1984;57:681-90.

18. Bohay RN, Stephens RG, Kogon SL. A study of the impact of screening or selective radiography on the treatment and postdelivery outcome for edentulous patients. Oral Surg Oral Med Oral Pathol Oral Radiol Endod 1998;86:353-9.

19. Ritchie GM, Fletcher AM. A radiographic investigation of edentulous jaws. Oral Surg Oral Med Oral Pathol 1979;47:563-7.

20. Spyropoulos ND, Patsakas AJ, Angelopoulos AP. Findings from radiographs of the jaws of edentulous patients. Oral Surg Oral Med Oral Pathol 1981;52:455-9

21. Ansari IH. Panoramic radiographic examination of edentulous jaws. Quintessence Int 1997;28:23-6.

22. Miloglu Ö, Yasa Y, Bayrakdar IŞ, Gungor $H$. Panoramic radiographic examination in a group of edentulous patients. J Dent Fac Atatürk Uni 2012;22:230-4.

23. Axelsson G. Orthopantomographic examination of the edentulous mouth. J Prosthet Dent. 1988; 59: 592-8.

24. McCrorie JW. An orthopantomogram survey of edentulous mouths. Dent Pract Dent Rec 1971; 22: 83-4.

25. Wyatt CC, Pharoah MJ. Imaging techniques and image interpretation for dental implant treatment. Protez: Int J Prosthodont. 1998;11:442-52.

26. Xie Q, Soikkonen K, Wolf J, Mattila K, Gong M, Ainamo A. Effect of head positioning in panoramic radiography on vertical measurements: an in vitro study. Dentomaxillofac Radiol. 1996;25:61-6.

27. Keur JJ, Campbell JP, McCarthy JF, Ralph WJ. Radiological findings in 1135 edentulous patients. J Oral Rehabil. 1987;14:183-91.

\section{Yazışma Adresi:}

Dr. A. Zeynep YILDIRIM BİÇER

Gazi Üniversitesi

Diş Hekimliği Fakültesi

Protetik Diş Tedavisi Anabilim Dalı

06510, Ankara, TÜRKİYE.

Tel: +90 3122034192

Fax: +90 3122239226

E-mail: dtzeynep@yahoo.com 